$\begin{array}{r}\text { Volume and Issues Obtainable at Center for Sustainability Research and Consultancy } \\ \text { Journal of Business and Social Review in Emerging Economies } \\ \text { ISSN: 2519-089X (E): 2519-0326 } \\ \text { Volume 6: No. 4, December } 2020 \\ \text { JSRC } \\ \text { Journal homepage: www.publishing.globalcsrc.org/jbsee } \\ \hline\end{array}$

\title{
Determinants of Customer Perception about Adoption of Islamic Insurance (Takaful) in Pakistan
}

\author{
${ }^{1}$ Areeba Khan, ${ }^{2}$ Hafiz Abdur Rashid, ${ }^{3}$ Rana Muhammad Shahid Yaqub, ${ }^{4}$ Saba Abbas \\ ${ }^{1,3 \& 4}$ IBMAS, The Islamia University of Bahawalpur, Pakistan, Areeba.khan@iub.edu.pk, \\ Shahid.yaqub@iub.edu.pk, Sabaabbasiub@gmail.com \\ ${ }^{2}$ Assistant Professor, Hailey College of Commerce, University of the Punjab, Lahore, Pakistan, \\ ha.rashid.hcc@gmail.com
}

\begin{tabular}{l}
\hline ARTICLE DETAILS \\
\hline History \\
Revised format: November \\
2020 \\
Available Online: December \\
2020 \\
Keywords \\
Takaful; Islamic Insurance; \\
PLS Smart; Customer \\
perception, Adoption, Social \\
Influence
\end{tabular}

JEL Classification

M4, M40

\section{ABSTRACT}

The purpose of this study is to assess the response level of individuals concerning Islamic Insurance in Pakistan and to measure its outreach and most pertinent factors affecting customer selection of Islamic Insurance. It also seeks to make informed recommendations on empowering frameworks for the establishment of Takaful insurance through relevant marketing campaigns in Pakistan. The impact of factors like Customer Awareness, Consumer Satisfaction, Risk Perception, Compatibility and Religiosity was checked on Adoption of Islamic Insurance in Pakistan, with the presence of Social Influence as a mediating variable. Data were collected through questionnaire administered to 300 respondents, representing the Muslim community from urban as well as rural areas, of Pakistan. Partial least square-structural equation modeling (PLSSEM) through Smart PLS3 was used to examine the relationships among pertinent factors in this study. The findings suggest that most respondents are either not aware of Takaful as an insurance and investment option, or do not understand the concept altogether. This study suggests that Islamic insurance organizations should focus on awareness campaigns as an essential marketing strategy and dedicated resources to reach prime customer segments in general and fulfil the need to inform people about their products and services through clear understanding of principles of Shariah compliance. The findings of this research have important implications for Takaful companies as well as regulators and general insurance customers.

(C) 2020 Center for Sustainability Research and Consultancy Pakistan under a Creative Commons Attribution-NonCommercial-ShareAlike

4.0

Corresponding author's email address: Areeba.khan@iub.edu.pk

Recommended citation: Khan, A., Rashid, H. A., Yaqub, R. M. S., \& Abbas, S. (2020). Determinants of Customer Perception about Adoption of Islamic Insurance (Takaful) in Pakistan. Journal of Business and Social Review in Emerging Economies, 6(4), 1505-1516 


\section{Introduction}

The past decade has seen the rapid emergence and growth of the Islamic financial services sector, which has obtained wide acknowledgment and recognition. Since its emergence, the worldwide Islamic finance industry has extended further than the conventional Islamic economic boundaries of the major industrial economy and has grown significantly (Abdullah, \& Abd Rahman, 2018; Tan \& Lim, 2019; ). Nowadays, Islamic Finance is not anymore a niche product used in a special market but is currently offered in more than 60 countries.

Internationally, the insurance market in developed countries is well-reputed and highly flourished (Souiden \& Jabeur, 2015). In particular, the Altuntas, Berry-Stölzle, and Hoyt (2011) record shows that Japanese citizens invest from their annual income of about 8.6 percent $(\$ 3,472)$ in the insurance division. Also, the record emphasizes that the market share of 79.1 percent of the Japanese insurance market, 69 percent in France and the UK and 43 percent in the USA. The insurance industry in emerging countries is in its starting point. Countries like Turkey, Tunisia, and Algeria, show 15.6 percent, 13.2 percent, and 7.5 percent of market share of over-all insurance industry claimed by Islamic Insurance (Takaful) (Outreville, 2018).

In Pakistan, the takaful industry is growing with existing and new players contemplating the introduction of Shiah-compliant products. This is the beginning of a major transformation in which the Shariacompliant insurance solutions may eventually become available to most Muslim people in the country. This further emphasizes the importance of study for Islamic consumer preferences. It is the consumer preferences that have given them the option to enjoy high-quality products and services. Also, Pakistani insurance companies allow customers to request insurance products and services that best suit their needs. Consumers have a lot of options to browse. Therefore, general and Islamic insurers need to compete more with the best products and services they can offer their customers. However, the possibilities do not arise incidentally. Many important questions must be discussed to ensure the credibility and acceptance of Takaful's bright future. Consequently, Takaful suppliers should be smart about their position in the product production phase which can meet market demands and respond positively to other mitigating factors that may reduce the tendency of Takaful subscribers. Furthermore, the awareness of the Takaful related products is still low in Pakistan as compared to other countries and poses a vital concern for Takaful providers (Jamshidi, Hussin, \& Wan, 2015). The perception that Takaful is similar to conventional insurance exhibits how little Pakistanis know about the Takaful mechanism (Akhter \& Khan, 2017). The above-given background has triggered the need for further investigation on the contributing factors that might influence the tendency to subscribe to a Takaful plan or products.

\section{Literature Review and Prepositioning}

"Islamic Insurance is a framework through which the members give part of the entirety of their commitments which are utilized to pay claims for losses endured by a portion of the members. The organization's job is confined to dealing with the insurance tasks and contributing to the insurance commitments." (Grassa, 2013). The act of Takaful agreement and business will be in coherence with the Islamic idea of shared co-operation based on the standards of al-Mudharabah, which is allowable as indicated by Allah (SWT), and is completed dependent on the just and true intention to guarantee the member with financial protection from unforeseen future material hazard. Later on, for a Takaful exchange to get legal and enforceable, it ought to be liberated from unlawful components, for instance, usury, extortion, and ahead. Takaful practices the idea of risk sharing, while the general insurance practice depends on risk transfer (Kasim, Htay, \& Salman, 2016). In Takaful, risk sharing among members is decided by taking at the danger support. This reserve is a Tabarru (gift, donation), or commonly contributed finance. It is utilized to pay claims for any outstanding losses or surplus. The excess is shared among the participants just as the operator does, oppose to the allowing of the Takaful model and Islamic law. The basic concept of Takaful is the idea of proportionate sharing, designed to 
promote association and solidarity between members and the community.

In 2005, the Islamic State Council enacted the guidelines of the Islamic insurance policy. In Pakistan, the concept of Takaful is very old; though its relevant effects may be new. In 1983, the Pakistani government encouraged the Islamic Ideology Council of Pakistan to suggest an Islamic insurance policy. From that point on, Islamic insurance faced a variety of conversational difficulties because of its complications and the non Shariah compliant environment. In 2005, the Islamic State Council set up standards for the Islamic insurance policy in the country. A large takaful organization, particularly the Pak-Kuwait Takaful limited company commenced their operations in 2006 based on Wakala-Waqf model. The SECP in recent times gave license to five more life insurance companies to elevate the market (Hanif \& Iqbal, 2017). Of estimated 200 million Pakistani people, access to insurance is very low when most people are left unprotected and unaware. Access to information in this scenario is the biggest challenge. As 75 percent of our people fall into the low-income bracket, the only viable consumer segment found in the insurance industry and Takaful is 25 percent of people who earn high, are educated, and have controlled access to their property. This still leaves a great percentage of unexploited consumers who are opting for voluntary exclusion from insurance.

By and large, the Takaful sector is at its evolving level over time, the industry will also need to produce products that show innovation, compatibility and transparency of Takaful to build new market sections. That will make the Takaful industry a default defense option and a viable tool for investment and securitization.

\subsection{Adoption of Islamic Insurance}

In the present research Adoption to Islamic Insurance (ADII) is a dependent variable used to identify the reasons why people have accepted or are interested in Islamic Insurance and the factors that contributing to its adoption. Arifin and Yazid (2018) refer to various factors affecting the adoption of Islamic insurance including aqilah and planning. Shariah scholars have been open about the contradictions in their beliefs about Insurance framework in Islam. Takaful is permissible as a vehicle, but Sharia sources provide a complete overview of the basics of framework, rules and regulations, failure to comply with which would render the vehicle inadmissible (Morrison, 2014).

\subsection{Customer Awareness}

The level of awareness about the Islamic Insurance product in urban areas of metropolitan cities, however, the greater part of the consumers is unaware of the Islamic financial products (Coolen-Maturi, 2013). Awareness means people develop their interest in certain issues and participate (Husin \& Ab Rahman, 2016a). In this study, Awareness is defined as knowledge level and approach of customers towards Islamic products and services of insurance companies. The first stage of acceptance of any product or service is awareness. It is therefore unthinkable that the adoption of any product would take place unless one knows about it. Awareness is therefore fundamental to the use of insurance products and services as it opens up a way to stimulate customer curiosity. Without awareness, there would be no customer action. L. Xu, Prybutok, and Blankson (2019) have identified awareness as a powerful factor that directs customer towards the acceptance or rejection of a particular product. Similarly, Bashir (2019) observed that creating awareness among consumers about a product or service remains a key factor in its acceptance. Literature reports the link between variables awareness and customers' acceptance and acceptance of a particular product, services, or idea (Hanafi, Kasim, \& Diyana, 2019). Based on the literature as discussed, the following hypothesis is developed:

H1: There exists a significant relationship between Customer awareness and Islamic Insurance adoption.

\subsection{Consumer Satisfaction}

Consumers' fulfilment can be viewed as a client's evaluation of the outcomes that they have obtained in 
collaboration with the organization, which results from the customer's pre-purchase surveys of anticipated performance with real performance (Hamzah, Ishak, \& Nor, 2015).

Consumers can think and choose Insurance options that will give them greater flexibility in terms of the materials and management are constantly educated about the commercial value due to the proliferation of new strategies (Narwal \& Sachdeva, 2013). Samir Roushdy and Ali (2017) state that customer satisfaction is significant as they are the ones who be responsible for customer service and affect customer understanding of Takaful. Based on the literature as discussed, the following hypothesis is developed:

H2: There exists a significant relationship between Customer satisfaction and Islamic Insurance adoption.

\subsection{Risk Perception}

Perceived risk is defines as nature and the amount of the uncertainty faced by the customer in his effort to make use of Islamic bank products or services. Tamer Asaad (2016) reports that the perceived risk of innovation is related to adoption of Islamic insurance services whereas other studies have shown a negative relationship between perceived risk and adoption (Guillemette, Hussein, Phillips, \& Martin, 2015; Mariadas \& Murthy, 2017).

Depending on the services of the leading insurance system, any type of service by Islamic insurance should be easy to read and use. The perceived ease of use can be explained as the "level of ease associated with system use", which helps and encourages customers to embrace and implement new programs (Thaker et al., 2019).

Based on the literature, the following hypothesis is developed:

H3: There exists a significant relationship between risk perception and Islamic Insurance adoption.

\subsection{Compatibility}

Compatibility refers to the level to which Islamic insurance products and services are seen as consistent with customer beliefs and values. It is also regarded as the harmony of insurance products and services in human justice, insurance practice, and the belief of recipients.

Perceived compatibility has been predicted to provide an impact on innovation adoption. The direct effect of this variable has been reported on individual behavior. Many studies have reported the relationship between compatibility and acceptance of a product or service. The relationship was guaranteed especially as positive and significant. Studies by Sidharta, Mentari, Wafaretta, and Nuraini (2017); Naicker and Van Der Merwe (2018) have revealed a positive relationship between compatibility and acceptance of Islamic insurance. Previous studies in various ways have confirmed the potential for adoption of new products or ideas if the new ones are considered to be in line with their beliefs, practices, current values, social system, and their values and lifestyles (Obeid \& Kaabachi, 2016; Liu \& $\mathrm{Yi}, 2017)$. Previous researches have noted that compatibility has a positive and significant relationship on the acceptance of Islamic insurance (Ali, Yaacob, \& Haji, 2018). Based on the literature as discussed, the following hypothesis is developed:

H4: There exists a significant relationship between compatibility and Islamic Insurance adoption.

\subsection{Religiosity}

The definition of religiosity is the level of a person that believes in God, built on his or her faithfulness and love of religion (Zakaria et al., 2016).

Religiosity is characterized by emotions, exhibition, and a gathering of people. Religiosity was seen as one of the significant components in the determination of Islamic Insurance with the ultimate goal of acquisition of items and for the assumption.

From the researches of Mathras, Cohen, Mandel, and Mick (2016), it is established that religion could 
influence customer psychology and behavior through beliefs, customs, qualities, and community. The Muslims are urged to buy Islamic insurance in light of the fact that the product is based on Islamic standards. That idea has characterized the items and administrations as "halal" and it conforms with the Muslim religion (Siala, 2013). Based on the literature as discussed, the following hypothesis is developed:

H5: There exists a significant relationship between religiosity and Islamic Insurance adoption.

\subsection{Mediating Role of Social Influence}

It is observed that the people may change their behavior because of the influence of a group of people or individuals. It is stated that people may consider the opinion of others and may influence their decision to do or not to do something (Husin et al., 2016).

Choosing the insurance commitment depends on five key decisions that include the proposal of partners, the reputation of the insurance, the cost of managing the accounts, the people considering, and the availability of credit. In the context of Islamic insurance, social influence has $53 \%$ of the functionality and is effective and positive. People choose Islamic insurance because society expects it from them (Echchabi et al., 2016). SI contributes to consumer loyalty through references, family members, and friends (Badowska, 2017; Beldad \& Hegner, 2018; Herawati \& Tjahjono, 2020).

Based on the literature as discussed, the following hypotheses are formulated:

H6: Social Influence significantly mediates the relationship between customer awareness and Islamic Insurance adoption.

H7: Social Influence significantly mediates the relationship between customer satisfaction and Islamic Insurance adoption.

H8: Social Influence significantly mediates the relationship between risk perception and Islamic Insurance adoption.

H9: Social Influence significantly mediates the relationship between compatibility and Islamic Insurance adoption.

H10: Social Influence significantly mediates the relationship between religiosity and Islamic Insurance adoption.

\section{Method}

Determining the appropriate research strategy allows the analyst to build interactive tools for data collection and analysis. The study is descriptive in nature and quantitative methodology is applied by obtaining a list of questions from the previous investigations.

Table 3.1: Description of Variables

\begin{tabular}{|c|c|c|c|c|}
\hline $\begin{array}{l}\text { Variables } \\
\text { Name }\end{array}$ & $\begin{array}{l}\text { Variables } \\
\text { code }\end{array}$ & Description & Investigation tool & References \\
\hline $\begin{array}{l}\text { Customer } \\
\text { Awareness }\end{array}$ & $\mathrm{CA}$ & $\begin{array}{l}\text { Awareness is a perception and customer } \\
\text { information about any particular product, } \\
\text { service, or situation. }\end{array}$ & Questionnaire & (Safari, 2019) \\
\hline $\begin{array}{l}\text { Consumer } \\
\text { Satisfaction }\end{array}$ & $\mathrm{CS}$ & $\begin{array}{l}\text { Customer satisfaction response, the extent } \\
\text { to which the completion is satisfactory or } \\
\text { unpleasant. }\end{array}$ & Questionnaire & (Mariadas \&Murty,2017) \\
\hline $\begin{array}{l}\text { Risk } \\
\text { Perception }\end{array}$ & $\mathrm{RP}$ & $\begin{array}{l}\text { The perceived risk can be defined as the } \\
\text { level and type of uncertainty consumers } \\
\text { experience in his or her attempt to use a } \\
\text { particular product or service. }\end{array}$ & Questionnaire & (Thaker et al, 2019) \\
\hline
\end{tabular}




\begin{tabular}{|l|l|l|l|l|}
\hline Compatibility & COM & $\begin{array}{l}\text { Compatibility is defined as the level at } \\
\text { which an innovation is considered be in } \\
\text { line with existing values past } \\
\text { experiences, and potential recipients' } \\
\text { needs. }\end{array}$ & Questionnaire \\
\hline Religiosity & REL & $\begin{array}{l}\text { Religiosity is defined as the feelings, } \\
\text { actions, and experiences of individuals. }\end{array}$ & Questionnaire & $\begin{array}{l}\text { (Obeid \& Kaabachi, } \\
\text { 2016) }\end{array}$ \\
\hline $\begin{array}{l}\text { Social } \\
\text { Influence }\end{array}$ & SI & $\begin{array}{l}\text { Social influence is peer pressure, people } \\
\text { perceiving it from their families, social } \\
\text { groups, and surroundings, which } \\
\text { influence their choice of behavior. }\end{array}$ & Questionnaire & (Bodibe et al, 2016) \\
\hline $\begin{array}{l}\text { Adoption of } \\
\text { insumic } \\
\text { insunce }\end{array}$ & Adopt & $\begin{array}{l}\text { Takaful is a Shariah way to protect } \\
\text { yourself and your family from future } \\
\text { financial losses. }\end{array}$ & Questionnaire \\
\hline
\end{tabular}

Convenience sampling is most common in Islamic finance research. The main reason for choosing this method is the lack of feedback from individuals, as individuals are completely unaware of the concept. Based on the convenience sampling, 300 respondents were selected and the impact of independent variables (awareness of the Islamic insurance system, customer satisfaction, compatibility, perceived risk, and social influence) was analyzed on the dependent variable (adoption of Islamic insurance) through administration of the questionnaire.

The instruments consists of 25 items were modified from the existing body of literature (Mariadas \& Murthy, 2017; Safari, 2019; Schmidt, 2019; Thaker et al., 2019). All the items were estimated on five points Likert scale. The instrument is divided into two segments. The first segment manages access to socio-demographic data about the respondents and the second segment focuses on seven variables, including one dependent, one mediating, and five independent variables. This section was linked to the collection details using five indicators that influence the acceptance of Islamic Insurance.

The use of the Smart-Partial Least Square Structural Equation Modeling (Smart PLS-SEM) method of analysis as a second-generation method of analysis was employed to examine the data. PLS-SEM was used to analyze the relationship of varying degrees and it is a more sophisticated multivariate data analysis to measure unobservable variables and to minimize measurement error (Chin, 1998). To sum it up, the Smart PLS-SEM technique has the advantage of analyzing a sample of various degrees, minimizing measurement error, and also serve as the source of confirmatory and exploratory analysis (Henseler et al., 2014).

\section{Findings and Discussion}

The initial phase in PLS-SEM is the measurement model evaluation. Reliability (factor loadings), internal consistency reliability (Cronbach's alpha) (composite reliability CR), construct validity (average variance extracted AVE), and discriminant validity (Fornell and Lacker ( $\mathrm{F}$ and $\mathrm{L}$ ) were run and analysed. The measurement outcomes were acquired after the running algorithm is SmartPLS and are presented in Table 4.1 .

Table 4.1 also exhibits the Cronbach's alpha for six factors of adoption of Islamic Insurance in Pakistan. The alpha qualities ran from 0.772 to 0.871 , more than the base model of 0.60 Cronbach's alpha which represents the rule of thumb for a reliability test as per Byrne and Van de Vijver (2010). Data analysis confirms the instrument is highly reliable because internal consistency is seen among all factors.

In this research, convergent validity was evaluated by factor loading, Composite Reliability (CR), and Average Variance Extracted (AVE) (Fornell \& Larcker, 1981). Confirmatory Factor Analysis (CFA) is 
directed to evaluate the factor loading of variables. As per this standard, the convergent validity of the measurement model can be surveyed by the Average Variance Extracted (AVE) and Composite Reliability (CR).

Table 4.1: Construct Validity and Reliability

\begin{tabular}{|c|c|c|c|c|c|}
\hline Construct & Items & Factor loading & $\begin{array}{l}\text { Cronbach's } \\
\text { Alpha } \\
(\alpha)\end{array}$ & CR & AVE \\
\hline \multirow{3}{*}{$\begin{array}{l}\text { Customer } \\
\text { Awareness }\end{array}$} & CA1 & 0.723 & \multirow[t]{3}{*}{0.721} & \multirow[t]{3}{*}{0.768} & \multirow[t]{3}{*}{0.631} \\
\hline & CA2 & 0.639 & & & \\
\hline & CA3 & 0.806 & & & \\
\hline \multirow{3}{*}{$\begin{array}{l}\text { Customer } \\
\text { Satisfaction }\end{array}$} & CS1 & 0.763 & \multirow[t]{3}{*}{0.604} & \multirow[t]{3}{*}{0.774} & \multirow[t]{3}{*}{0.537} \\
\hline & $\mathrm{CS} 2$ & 0.788 & & & \\
\hline & CS3 & 0.664 & & & \\
\hline \multirow[t]{4}{*}{ Risk Perception } & RP1 & 0.586 & \multirow[t]{4}{*}{0.648} & \multirow[t]{4}{*}{0.787} & \multirow[t]{4}{*}{0.687} \\
\hline & RP3 & 0.803 & & & \\
\hline & RP4 & 0.691 & & & \\
\hline & RP5 & 0.691 & & & \\
\hline \multirow[t]{3}{*}{ Compatibility } & COM1 & 0.672 & \multirow[t]{3}{*}{0.633} & \multirow[t]{3}{*}{0.803} & \multirow[t]{3}{*}{0.578} \\
\hline & COM2 & 0.835 & & & \\
\hline & COM3 & 0.769 & & & \\
\hline \multirow[t]{5}{*}{ Religiosity } & REL1 & 0.684 & \multirow[t]{5}{*}{0.725} & \multirow[t]{5}{*}{0.816} & \multirow[t]{5}{*}{0.582} \\
\hline & REL2 & 0.724 & & & \\
\hline & REL3 & 0.561 & & & \\
\hline & REL4 & 0.712 & & & \\
\hline & REL5 & 0.745 & & & \\
\hline \multirow[t]{3}{*}{ Social Influence } & SI1 & 0.796 & \multirow[t]{3}{*}{0.697} & \multirow[t]{3}{*}{0.832} & \multirow[t]{3}{*}{0.623} \\
\hline & SI2 & 0.757 & & & \\
\hline & SI3 & 0.814 & & & \\
\hline \multirow{4}{*}{$\begin{array}{l}\text { Adopt of Islamic } \\
\text { Insurance }\end{array}$} & Adopt1 & 0.712 & \multirow[t]{4}{*}{0.684} & \multirow[t]{4}{*}{0.807} & \multirow[t]{4}{*}{0.515} \\
\hline & Adopt2 & 0.785 & & & \\
\hline & Adopt3 & 0.781 & & & \\
\hline & Adopt4 & 0.570 & & & \\
\hline
\end{tabular}

Table 4.2: Discriminant Validity

\begin{tabular}{|l|l|l|l|l|l|l|l|}
\hline & Adopt & CA & COM & CS & REL & RP & SI \\
\hline Adopt & 0.717 & & & & & & \\
\hline CA & 0.422 & 0.726 & & & & & \\
\hline COM & 0.642 & 0.398 & 0.762 & & & & \\
\hline CS & 0.271 & 0.355 & 0.432 & 0.740 & & & \\
\hline REL & 0.592 & 0.378 & 0.591 & 0.396 & 0.688 & & \\
\hline RP & 0.517 & 0.501 & 0.548 & 0.524 & 0.531 & 0.697 & \\
\hline
\end{tabular}




\begin{tabular}{|l|l|l|l|l|l|l|l|}
\hline SI & 0.657 & 0.381 & 0.623 & 0.335 & 0.641 & 0.597 & 0.789 \\
\hline
\end{tabular}

The measurement model has acceptable discriminant validity. Besides, since the measurement model of this examination indicated an acceptable degree of reliability and validity, further investigation could be accomplished to survey the structural model and followed by hypotheses testing.

After the analysis of the measurement model, the structural model was examined. The significance of the structural model was measured by R square value. As displayed in Table 4.3, R2 for adoption is 59\% and social influence was $55 \%$ suggesting that the model has substantial explanatory power.

Table 4.3: Significance of Structural Model

\begin{tabular}{|l|l|}
\hline Construct & R Square \\
\hline Adopt & 0.595 \\
\hline SI & 0.552 \\
\hline
\end{tabular}

To test the hypothesized relationships among the constructs, the estimates were acquired for the path coefficients. SmartPLS can produce $T$-statistics for significance testing of both the internal and external models, using bootstrapping. Table 4.4 presents the hypotheses relationships among the constructs.

$\mathrm{H} 1$ shows the relation between customer awareness and adoption of Islamic Insurance, which is accepted by having a $\mathrm{B}=0.122, \mathrm{P}=0.001$ and $\mathrm{T}$ statistics $2.445, \mathrm{H} 2$ reveals the relationship between customer satisfaction and adoption of Islamic insurance which presents an inverse relation with $\mathrm{B}=-$ $0.116, \mathrm{P}=0.009$ and $\mathrm{T}$ statistics 2.612 which is accepted, $\mathrm{H} 3$ represents the relationship between risk perception and adoption of Islamic insurance that is rejected $\mathrm{B}=0.071, \mathrm{P}=0.304$ and T statistics 1.028. $\mathrm{H} 4$ presents the relationship between compatibility and adoption of Islamic Insurance. The results displays a significant relationship with $\mathrm{B}=0.314, \mathrm{P}=0.000$, and $\mathrm{T}$ statistics 6.191 . H5 indicates a significant positive relationship between religiosity and adoption of Islamic Insurance, i.e. $\mathrm{B}=0.075, \mathrm{P}=$ 0.000 , and T statistics 4.572 .

Table 4.4 Structural Model Analysis

\begin{tabular}{|l|l|l|l|l|l|}
\hline Hypotheses & Relationship & Path Coefficient & T- Statistics & P-value & Decision \\
\hline H1 & CA -> Adopt & 0.122 & 2.445 & 0.001 & Significant \\
\hline H2 & CS ->Adopt & -0.116 & 2.612 & 0.009 & Significant \\
\hline H3 & RP ->Adopt & 0.071 & 1.018 & 0.304 & Insignificant \\
\hline H4 & COM ->Adopt & 0.314 & 6.191 & 0.000 & Significant \\
\hline H5 & REL -> Adopt & 0.075 & 4.572 & 0.000 & Significant \\
\hline
\end{tabular}

To test the mediation relationship proposed in H6, the current study bootstrapped the direct effect of customer awareness on the adoption of Islamic Insurance and there is no mediation. It is found that the test was insignificant with t statistics $=0.406$, p-value $=0.685$, therefore $\mathrm{H} 6$ is rejected. Further, to test the mediation suggested in $\mathrm{H7}$, the current study bootstrapped the direct effect of customer satisfaction on the adoption of Islamic Insurance. The test was insignificant with t statistics $=1.438, \mathrm{p}$-value $=0.151$. Having these results, this study found that social Influence did not play a mediating role between customer satisfaction and adoption of Islamic Insurance. In H8 social influence plays a mediating role between risk perception and adoption of Islamic Insurance. It was found that the test was significant with $\mathrm{t}$ statistics $=3.463$, $\mathrm{p}$-value $=0.001$. In $\mathrm{H} 9-\mathrm{H} 10$ social influence plays a mediating role in 
compatibility and religiosity. Is it found that the test was significant with $\mathrm{t}$ statistics $=3.589$, $\mathrm{p}$ value $=0.000$ so, H9 is accepted and t statistics $=3.547$, p-value $=0.000$ of H10. Therefore H9 and H10 are accepted. There is full mediation between customer awareness and customer satisfaction and partial mediation exists in risk perception, compatibility, and religiosity.

Table 4.5: Structural Model with Mediation

\begin{tabular}{|l|lr|l|l|l|l|l|}
\hline Hypotheses & \multicolumn{2}{|l|}{ Relationship } & Beta & t-value & P-value & decision & Conclusion \\
\hline H6 & $\begin{array}{l}\text { CA -> } \\
\text { Adopt }\end{array}$ & SI-> & 0.006 & 0.406 & 0.685 & Insignificant & Full Mediation \\
\hline H7 & $\begin{array}{l}\text { CS >> SI- } \\
>\text { Adopt }\end{array}$ & -0.025 & 1.438 & 0.151 & Insignificant & Full Mediation \\
\hline H8 & $\begin{array}{l}\text { RP -> SI- } \\
>\text { Adopt }\end{array}$ & 0.086 & 3.463 & 0.001 & Significant & $\begin{array}{l}\text { Partial } \\
\text { Mediation }\end{array}$ \\
\hline H9 & $\begin{array}{l}\text { COM >> SI- } \\
\text { Adopt }\end{array}$ & 0.086 & 3.589 & 0.000 & Significant & $\begin{array}{l}\text { Partial } \\
\text { Mediation }\end{array}$ \\
\hline H10 & $\begin{array}{l}\text { REL -> SI- } \\
>\text { Adopt }\end{array}$ & 0.101 & 3.547 & 0.000 & Significant & $\begin{array}{l}\text { Partial } \\
\text { Mediation }\end{array}$ \\
\hline
\end{tabular}

Awareness of Islamic insurance impacts customer acceptance of Islamic insurance products in a significant manner. That outcome is coherent with the findings of earlier literature ( Karbhari et al., 2018). Awareness of Islamic insurance was also consistent with the findings of Hisham, Palil, Nowalid, and Ramli (2019) and Safari (2019). It exhibits that the hightened customer awareness prompts a surge in the adoption of Islamic Insurance.

From the results, the level of customer satisfaction negatively affects customer adoption toward takaful products. This finding is interesting as it relates to earlier studies conducted by Janahi and Al Mubarak (2017) and Mariadas and Murthy (2017). Therefore, the findings suggest that satisfaction is a determinant of Takaful adoption. The empirical results of my findings indicate that people do not have high satisfaction in Takaful. Therefore, Takaful operators should increase the Takaful perceptions among conventional insurance customers to recognize its importance to create more satisfied Takaful customers.

From the results, risk perception does not seem to significantly influence the adoption of Islamic Insurance these outcomes are similar to previous studies of Thaker et al. (2019). The outcome shows that 'Perceived Risk' is not a significant variable in the adoption of takaful and doesn't have a direct relationship. That clarifies why customers observe 'Perceived Risk' as irrelevant in their choice to embrace Islamic insurance.

In addition, compatibility impacts customer adoption attitude toward Islamic insurance. The outcome suggests that respondents have confidence in Islamic insurance items and its similarity. It is also endorsed that Takaful items are steady with their moral qualities, religious belief, and satisfy their desires regarding financial needs. It concludes that the more compatible the people are, the easier they will feel to purchase Islamic insurance.

This study endorses a causal relationship between compatibility and customer intention towards Islamic insurance. Finally, the findings suggest that religiosity has an impact on the acceptance level of customers toward Islamic insurance. The foundation of Islamic insurance is religion, therefore, religion understandably had to be the most dominant reason which induces Muslims to switch from conventional insurance to Takaful. 


\section{Conclusion and Policy Recommendations}

It is concluded that religiosity is a significant element in purchasing Islamic insurance, while customer satisfaction with the current conventional insurance reduces its purchasing. Risk perception is not considered a factor in the adoption of Islamic Insurance. Therefore, in the presence of social influence, the risk perception considered significant factors towards the adoption behavior, and social influence is also considered a mediator between compatibility and religiosity in the adoption of Takaful.

It is recommended that to increase Takaful outreach among conventional customers, their attitude towards Takaful ought to be positively shaped by developing mass awareness campaigns through proper channels including advertisement that show Takaful operations and benefits, and its difference from traditional insurance. Customer of Pakistan perceives Takaful positively though there is dire need of conveying the details on Takaful through social media, interactive websites, or face to face meetings.

\section{References}

Ali, Q., Yaacob, H. B., \& Haji, D. H. N. B. D. (2018). Empirical Investigation of Islamic Banking Adoption in Brunei. International Journal of Islamic Banking and Finance Research, 2(2), 24-38.

Altuntas, M., Berry-Stölzle, T. R., \& Hoyt, R. E. (2011). Implementation of enterprise risk management: Evidence from the German property-liability insurance industry. The Geneva papers on risk and insurance-issues and practice, 36(3), 414-439.

Arifin, J., \& Yazid, A. S. (2018). The influence of innovation attributes on loyalty in family takaful: A conceptual study. South East Asia Journal of Contemporary Business, Economics and Law, 15(1), 1-8.

Badowska, S. (2017). Social influence and a process of acceptance and use of a technological product by the elderly consumers. Annales Universitatis Mariae Curie-Skłodowska, Sectio H Oeconomia, 51(2), 29-37.

Bashir, A. M. (2019). Effect of halal awareness, halal logo and attitude on foreign consumers' purchase intention. British Food Journal.

Beldad, A. D., \& Hegner, S. M. (2018). Expanding the technology acceptance model with the inclusion of trust, social influence, and health valuation to determine the predictors of German users' willingness to continue using a fitness app: A structural equation modeling approach. International Journal of Human-Computer Interaction, 34(9), 882-893.

Bodibe, S., Chiliya, N., \& Chikandiwa, C. T. (2016). The factors affecting customers' decisions to adopt Islamic banking. Banks \& bank systems(11, Iss. 4 (cont.)), 144-151.

Chin, W. W. (1998). The partial least squares approach to structural equation modeling. Modern methods for business research, 295(2), 295-336.

Coolen-Maturi, T. (2013). Islamic insurance (takaful): demand and supply in the UK. International Journal of Islamic and Middle Eastern Finance and Management.

Echchabi, A., Azouzi, D., \& Aziz, H. A. (2016). The future prospects of Islamic banking in Tunisia: an empirical survey. EuroMed Journal of Business.

Fornell, C., \& Larcker, D. F. (1981). Structural equation models with unobservable variables and measurement error: Algebra and statistics: Sage Publications Sage CA: Los Angeles, CA.

Grassa, R. (2013). Shariah supervisory system in Islamic financial institutions. Humanomics.

Guillemette, M., Hussein, M., Phillips, G. M., \& Martin, T. (2015). Minority household size and the life insurance purchase decision. Financial Services Review.

Hanafi, H., Kasim, N. H., \& Diyana, S. (2019). Islamic Mortgage Products: How Aware are Malaysians? Pertanika Journal of Social Sciences \& Humanities, 27(1).

Hanif, M., \& Iqbal, A. M. (2017). An evaluation of Takaful insurance: case of Pakistan. Journal of Islamic Economics, Banking and Finance, 113(6218), 1-26.

Henseler, J., Dijkstra, T. K., Sarstedt, M., Ringle, C. M., Diamantopoulos, A., Straub, D. W., . . . Calantone, R. J. (2014). Common beliefs and reality about PLS: Comments on Rönkkö and Evermann (2013). Organizational research methods, 17(2), 182-209.

Herawati, R., \& Tjahjono, H. K. (2020). The Influence of Instructional Leadership on Professional Competence Mediated by Self-Efficacy and Social Capital. Jurnal Manajemen Bisnis, 11(2). 
Hisham, R. R. I. R., Palil, M. R., Nowalid, W. A. W. M., \& Ramli, M. R. (2019). Islamic Leadership and Transparency Practices in Takaful Organization. Asian Journal of Accounting and Governance, 11 .

Husin, M. M., Ismail, N., \& Ab Rahman, A. (2016). The roles of mass media, word of mouth and subjective norm in family takaful purchase intention. Journal of Islamic Marketing.

Janahi, M. A., \& Al Mubarak, M. M. S. (2017). The impact of customer service quality on customer satisfaction in Islamic banking. Journal of Islamic Marketing.

Karbhari, Y., Muye, I., Hassan, A. F. S., \& Elnahass, M. (2018). Governance mechanisms and efficiency: Evidence from an alternative insurance (Takaful) market. Journal of International Financial Markets, Institutions and Money, 56, 71-92.

Kasim, N., Htay, S. N. N., \& Salman, S. A. (2016). The religious perspective of Takaful as ethical insurance. Mediterranean Journal of Social Sciences, 7(4), 96.

Latip, M., Yahya, M., \& Junaina, M. (2017). Factors Influencing Customer's Acceptance of Islamic Banking Products and Services. Ikonomika, 2(1), 1-18.

Liu, P., \& Yi, S.-p. (2017). The effects of extend compatibility and use context on NFC mobile payment adoption intention Advances in Human Factors and System Interactions (pp. 57-68): Springer.

Mariadas, P. A., \& Murthy, U. (2017). Factors Influencing the Adoption of Islamic Banking in Malaysia. International Journal of Business and Management, 12(11), 187-193.

Mathras, D., Cohen, A. B., Mandel, N., \& Mick, D. G. (2016). The effects of religion on consumer behavior: A conceptual framework and research agenda. Journal of Consumer Psychology, 26(2), 298-311.

Morrison, S. (2014). Shariah boards and the corporate governance of Islamic banks in the United Kingdom. Journal of Islamic Economics, Banking and Finance, 113(3250), 1-14.

Naicker, V., \& Van Der Merwe, D. B. (2018). Managers' perception of mobile technology adoption in the Life Insurance industry. Information Technology \& People.

Abdullah, A., \& Abd Rahman, S. (2018). Knowledge And Application Of Islamic Financial Planning Among Small And Medium Enterprises Halal Operators In Peninsular Of Malaysia. Journal of Business Innovation, 2(1), 14-24.

Obeid, H., \& Kaabachi, S. (2016). Empirical investigation into customer adoption of Islamic banking services in Tunisia. Journal of Applied Business Research (JABR), 32(4), 1243-1256.

Outreville, J. F. (2018). Culture and Life Insurance Ownership: Is It an Issue? Journal of Insurance Issues, 41(2), 168-192.

Safari, M. (2019). A Conceptual Model to Explain Key Factors Affecting Islamic Banking Acceptance Among Banks and Financial Services' Customers. South Asian Journal of Marketing \& Management Research, 9(7), 13-29.

Schmidt, A. P. (2019). The impact of cognitive style, consumer demographics and cultural values on the acceptance of Islamic insurance products among American consumers. International Journal of Bank Marketing.

Seah, C. L., Tan, Y. X., Ong, K. Y., Lim, C. H., \& Choong, J. B. (2017). Factors that affect non-Muslim customers preference against Islamic deposit products in Malaysia. UTAR.

Siala, H. (2013). Religious influences on consumers' high-involvement purchasing decisions. Journal of services marketing.

Sidharta, E. A., Mentari, S., Wafaretta, V., \& Nuraini, U. (2017). Attitude and perception towards Sharia insurance product. International Journal of Business and Commerce, 6(5), 11-23.

Souiden, N., \& Jabeur, Y. (2015). The impact of Islamic beliefs on consumers' attitudes and purchase intentions of life insurance. International Journal of Bank Marketing.

Tamer Asaad, D. (2016). Antecedents of Channel Choice in Business-To-Business Professional Services: Focus on the Insurance Sector. Journal of Marketing Management, 4(2), 35-48.

Thaker, M. A. B. M. T., Pitchay, A. B. A., Thaker, H. B. M. T., \& Amin, M. F. B. (2019). Factors influencing consumers' adoption of Islamic mobile banking services in Malaysia. Journal of Islamic Marketing.

Zakaria, Z., Azmi, N. M., Hassan, N., Salleh, W. A., Tajuddin, M., Sallem, N., \& Noor, J. M. M. (2016). 
The intention to purchase life insurance: A case study of staff in public universities. Procedia Economics and Finance, 37(16), 358-365. 